\title{
HALREV
}

Hasanuddin Law Review

\section{Penegakan Hukum Lingkungan di Sektor Kehutanan (Studi Kawasan Hutan Lindung di Kabupaten Sinjai, Sulawesi Selatan)}

\author{
The Environmental Law Enforcemnent in Forestry Sector \\ (Study on the Protected Forest in Sinjai Region, South Sulawesi)
}

\author{
A. M. Yunus Wahid ${ }^{1}$, Naswar Bohari' ${ }^{1}$ Achmad $^{2 *}$ \\ ${ }^{1}$ Bagian Hukum Tata Negara, Fakultas Hukum, Universitas Hasanuddin. \\ Jln. Perintis Kemerdekaan Km. 10, Tamalanrea, Makassar, Sulawesi Selatan, 90245, Indonesia. \\ ${ }^{2}$ Bagian Hukum Keperdataan, Fakultas Hukum, Universitas Hasanuddin. \\ Jln. Perintis Kemerdekaan Km. 10, Tamalanrea, Makassar, Sulawesi Selatan, 90245, Indonesia.
}

*Tel./Fax:+62-411587219 E-mail: achmad_law@yahoo.co.id

Submitted: Feb 12, 2015; Reviewed: Mar 9, 2015; Accepted: Mar 24, 2015

\begin{abstract}
This research is designated to find how far the law performed in order to protect the Protected Forrest area, and the law enforcement in Sinjai region. This research is also to find out the problems that occur in the process of law enforcement. This research uses normative judiciary method, also combined with field research to gain some other facts that affected the law enforcement in the protected forest area. The research finds that in Sinjai region, there is still some activities that will affect the forest function. Some people said that there is no marking in the forest area around their village so they don't recognize the area as a protected part of the forest. In the law enforcement field, some obstacles existed, such as lack of budget in maintaining patrol, also the ranger need some special vehicles and weapon (fire arms) to give them security in order to fulfill their duties.
\end{abstract}

Keywords: Environmental Law; Protected Forest; Law Enforcement

\begin{abstract}
Abstrak: Penelitian ini bertujan untuk mengetahui sejauhmana pelaksanaan penegakan hukum dalam perlindungan hukum terhadp hutan lindung di kabupaten Sinjai, serta kendala-kendala yang dihadapi dalam pelaksanaannya. Penelitian dilaksanakan dengan metode yuridis normatif, disertai penelitian lapangan sebagai data pembanding. Tingginya angka deforestasi di Indonesia adalah inti dari permasalahan yang dibahas dalam penlitian ini. Okupasi lahan hutan oleh warga masyarakat menjadi area perkebunan atau pertanian, penebangan liar, serta pengalihan fungsi hutan lindung sangat berdampak pada pemanfaatan kawasan hutan. Sinergi antar instansi yang terlibat dalam perlindungan dan pengawasan kawasan hutan lindung mutlak diperlukan dalam upaya pelestarian hutan.
\end{abstract}

Kata Kunci: Hukum Lingkungan; Hutan Lindung; Penegakan Hukum 


\section{PENDAHULUAN}

Hukum lingkungan merupakan salah satu sarana penunjang dalam upaya mewujudkan perlindungan dan pengelolaan lingkungan hidup (PPLH) ${ }^{1}$ secara optimal. Hukum lingkungan khususnya dalam peraturan perundang-undangan sudah relatif memadai, baik kuantitas maupun kualitasnya, sehingga diharapkan dapat berfungsi dengan baik. Hukum lingkungan yang baik dan relatif lengkap ini, sebagaimana juga hukum pada umumnya, ia tetap dalam dirinya sebagai sarana belaka berupa benda mati belaka. Untuk dapat membawa kebaikan dalam PPLH, hukum lingkungan ini harus dihidupkan dan diterapkan dalam kehidupan nyata oleh manusia. Oleh karena itu, ia memerlukan sejumlah orang yang mau dan mampu menghidupkan dan menerapkannya dalam kehidupan secara nyata.

Penegakan hukum lingkungan di sektor kehutanan memegang peran penting, baik untuk kegiatan sektor kehuatan sendiri maupun dalam upaya pelestarian fungsi sumber daya alam (SDA) dan lingkungan hidup sebagai tujuan utama PPLH. Hutan sebagai SDA, memiliki fungsi ekonomi, sosial, budaya dan ekologis yang amat penting bagi kehidupan manusia dan makhluk lainnya yang tidak dapat digantikan oleh sumber daya lainnya. Kerusakan dan terganggunya fungsi-fungsi hutan secara langsung berpengaruh terhadap sistem kehidupan, baik ekosistem maupun sosiosistem yang pada gilirannya mengancam kehidupan umat manusia. Oleh karena itu, tidak ada pilihan lain

1 Undang-Undang Nomor 23 Tahun 1997 (UUPLH) menggunakan istilah 'Pengelolaan Lingkungan Hidup' (PLH). kecuali menjaga dan memelihara kelestarian fungsi-fungsi hutan tersebut, antara lain dengan atau melalui penegakan hukum lingkungan sebagai salah satu sarana penjang dalam PPLH.

Dalam rangka memperoleh manfaat yang optimal bagi kesejahteraan masyarakat, pada dasarnya kawasan hutan dapat dimanfaatkan dengan tetap memperhatikan sifat, karakteristik, dan kerentanannya, serta tidak dibenarkan mengubah suatu kawasan hutan yang memiliki fungsi perlindungan, dan harus dilakukan kajian yang mendalam serta komperhensif. $^{2}$

Namun pada kurun waktu yang bersamaan, masalah dan tantangan yang dihadapi dalam PPLH, juga cenderung meningkat baik kualitas maupun kuantitasnya. Masalah muncul susul menyusul termasuk masalah pemanasan global yang kini menjadi perhatian dunia. Semburan lumpur gas, banjir, kekeringan, tanah longsor dan lahan kritis yang tampaknya progresif dengan waktu terdapat di mana-mana. Lahan kritis di Kalimantan misalnya, pada tahun 2000 seluas 7.178.726 Ha meningkat menjadi 27.918.049 Ha pada tahun 2006, ${ }^{3}$ atau meningkat 4.653.008 Ha pertahun. Adanya kemerosotan hutan secara kuantitas dan kualitas yang progresif dengan waktu menunjukkan bahwa penegakan hukum lingkungan di sektor kehutanan belum berjalan optimal. Penegakan hukum lingkungan dalam arti luas, termasuk di sektor kehutanan merupakan amanat konstitusi

2 Iskandar. (2011). “Aktualisasi Prinsip Hukum Pelestarian Fungsi Lingkungan Hidup dalam Kebijakan Perubahan Peruntukan, Fungsi, dan Penggunaan Kawasan Hutan". Jurnal Dinamika Hukum, 11(3): 532-547

3 Sumber: Kompas, Rabu, 24 Juni 2009. 
bagi penyelenggara negara atau pemerintahan dalam upaya pemenuhan hak atas LH yang baik dan sehat secara berkelanjutan sebagai bagian dari HAM tersebut.

Kawasan hutan di Indonesia tercatat seluas 104.876.635 atau sekitar 54,6\% dari keseluruhan total luas daratan. Rinciannya, kawasan suaka alam dan kawasan pelestarian alam perairan 5.085.209 hektar (terdiri atas 27 unit) dan daratan 18.154.507 hektar (339 unit). Kawasan hutan tersebut terbagi dalam dua kategori. Pertama, kawasan suaka alam yang terdri atas cagar alam 2.283.142 hektar (168 unit) dan suaka margasatwa 3.612.323 hektar (4 unit). Sementara kawasan hutan pelestarian alam meliputi Taman Wisata 299.117 hektar (75 unit), Taman Buru 248.932 hektar (13 unit), Taman Nasional 11.458.993 hektar (30 unit) dan Taman Hutan Raya 252.089 hektar (11 unit). Selain kawasan suaka alam dan pelestarian alam, luas dan distribusi kawasan hutan juga terdiri atas hutan lindung seluas 30.581.753 hektar yang terdiri atas 472 Daerah Aliran Sungai (DAS). 62 DAS diantaranya termasuk DAS prioritas I, 232 DAS prioritas II dan 176 DAS prioritas III. Terakhir, kawasan hutan produksi yang terdiri atas Hutan Produksi Terbatas (HPT) 17.063.682 hektar, Hutan Produksi Tetap (HPT) seluas 28.675.881 hektar dan Hutan Produksi Konversi (HPK) seluas 13.717.786 hektar. $^{4}$

Bertolak dari data luas hutan yang terdapat di Indonesia di atas, untuk mencegah jangan sampai hutan mengalami penyusutan setiap hari, perlu dilakukan suatu pendekatan

4 Agung Nugraha. (2004). Menyonsong Perubahan Menuju Evitalisasi Sektor Kehutanan. Jakarta: Wirma Aksara, hlm. 58-59 yang bijak. Salah satu cara yang ditempuh adalah dengan pendekatan pengelolaan hutan dan hasil hutan yang dilakukan secara terencana dan bijaksana sesuai dengan peraturan perundang-undangan yang berlaku, khususnya peraturan dibidang kehutanan guna mencegah dan meminimalisir kerusakan hutan dalam mewujudkan pengelolaan hutan yang berkelanjutan.

Di Kabupaten Sinjai, yang secara total memiliki kawasan hutan seluas18.894 ha, terdiri dari 11.794 Hutan Lindung dan 7.100 Hutan produksi. Kawasan tersebut diantaranya merupakan satu kawasan hutan yang berada di lereng pegunungan Lompobattang - Bawakaraeng. Kawasan hutan Kabupaten Sinjai berbatasan langsung dengan Hutan lindung yang berbatasan dengan Kabupaten Gowa.

Berdasarkan data Dinas kehutanan dan Perkebunan Kabupaten Sinjai Tahun 2002, ada potensi areal yang sudah diokupasi oleh warga sekitar 4.261,5 ha atau sekitar 22.55\% ${ }^{5}$. Hal ini tentu saja menjadi suatu masalah tersendiri, karena keberadaan kawasan hutan tersebut sebagai daerah serapan air dan mencegah banjir bandang yang pernah terjadi 19 Juni 2006 dan menyebabkan 158 orang meninggal dunia. ${ }^{6}$ Berangkat dari peristiwa tersebut, Pemerintah Kabupaten Sinjai kemudian melakukan upaya-upaya pencegahan kerusakan kawasan hutan dengan memaksimalkan segala peraturan

5 Data persebaran kawasan hutan di Kabupaten Sinjai, Dinas Kehutanan dan Perkebunan Kabupaten Sinjai, 20 Januari 2003.

6 Sebagaimana dikutip pada laman website: merdeka.com/pernik/158-tewas-dalam-banjirbandang-di-sinjai-sulsel-bmshx8p.html. [Diakses tanggal 6 Februari 2014]. 
yang ada, untuk menjaga agar hal tersebut tidak terjadi lagi.

Berpijak dari isu hukum penegakan hukum lingkungan di atas, maka objek kajian pada penelitian ini dirumuskan sebagai berikut: Pertama, bagaimana efektivitas penegakan hukum lingkungan di sektor kehutanan di Kabupaten Sinjai? Kedua, sejauhmana sinergitas antara instansi penegak hukum dan instansi kehutanan dalam Pengelolaan dan Perlindungan kawasan hutan di Kabupaten Sinjai? Ketiga, faktor-faktor apa saja yang mempengaruhi pengelolaan dan Perlindungan kawasan Hutan di Kabupaten Sinjai?

\section{METODE}

Penelitian ini dilakukan di daerah Kabupaten Sinjai. Daerah ini dipilih karena memiliki kawasan hutan lindung yang memegang fungsi penting dalam pelestarian fungsi SDA dan lingkungan hidup, yang mulai mengalami perambahan untuk kepentingan ekonomi.

Populasi penelitian ini adalah keseluruhan pejabat atau aparat yang menangani masalah kehutanan di daerah penelitian. Adapun sampel penelitian ini ditetapkan dengan teknik purposive sampling dengan menggunakan kriteria berdasarkan karakteristik masing-masing yang terdiri dari pejabat instansi lingkungan hidup, pejabat instansi kehutanan, dan aparat pro justitia masingmasing aparat kepolisian, kejaksaan dan hakim, serta warga masyarakat yang bermukim di sekitar hutan lindung, sebagai pembanding dan mengetahui efektivitas penerapan hukum dalam bidang kehutanan dikalangan masyarakat.
Data yang diperoleh di lapangan akan dianalisis secara kualitatif, yakni analisis yang mendeskripsikan data yang diperoleh, baik data primer maupun data sekunder yang tidak dapat dikuantifikasi, sehingga harus diberi interpretasi dan simpulan.

\section{ANALISIS DAN PEMBAHASAN Deskripsi Lokasi Penelitian}

Secara geografis Kabupaten Sinjai terletak pada koordinat antara $5^{\circ} 2$ '56" sampai 5'21'16" Lintang Selatan dan 119'56'30" sampai $120^{\circ} 25^{\prime} 33^{\prime \prime}$ Bujur Timur. ${ }^{7}$ Luas wilayah Kabupaten Sinjai adalah 819,96 $\mathrm{km} 2$. Secara administratif, pemerintahan Kabupaten Sinjai terbagi dalam 9 kecamatan definitif yang terdiri dari 67 desa, 13 kelurahan, dan 349 dusun/lingkungan.

Dari total luas Kabupaten Sinjai, $31,25 \%$ mempunyai kemiringan tanah di atas 40 derajat, yaitu pada wilayah Kecamatan Sinjai Barat, Sinjai Tengah, Sinjai Borong, Bulu Poddo, dan Tellu Limpoe. Dengan bentuk topografi wilayah yang sebagian besar berupa dataran tinggi, wilayah Kabupaten Sinjai dilalui oleh 6 sungai besar dan kecil yang sangat potensial sebagai sumber tenaga listrik dan untuk pengairan/irigasi. Adapun sungai-sungai yang terdapat di Kabupaten Sinjai masih berada dalam wilayah satuan Sungai Je'ne Berang.

\section{Landasan Teori}

\section{Teori Penegakan Hukum}

Penegakan hukum merupakan ujung tombak terciptanya tatanan hukum yang baik

7 Sumber data sebagaimana dikutip pada laman website: http://www.sinjaikab.go.id/v2/index. php? option $=$ com content $\&$ view $=$ article\&id [Diakses pada tanggal 16 Mei 2014]. 
dalam masyarakat. Satjipto Rahardjo mengemukakan bahwa penegakan hukum pada hakikatnya merupakan penegakan ide-ide atau konsep-konsep yang abstrak. Penegakan hukum adalah usaha untuk mewujudkan ideide tersebut menjadi konkret. ${ }^{8}$

Penegakan hukum secara konkret menurut Sjachran Basah adalah berlakunya hukum positif dalam praktik sebagaimana seharusnya patut ditaati. Oleh karena itu, memberikan keadilan dalam suatu perkara berarti memutuskan perkara dengan menerapkan hukum dan menemukan hukum in concreto dalam mempertahankan dan menjamin ditaatinya hukum materiil dengan menggunakan cara prosedural yang ditetapkan oleh hukum formil. ${ }^{9}$

Secara umum, menurut Moestadji, ${ }^{10}$ penegakan hukum dapat diartikan sebagai tindakan menerapkan perangkat sarana hukum yang dimaksudkan untuk memaksakan sanksi hukum guna menjamin penataan ketentuan yang ditetapkan. Dalam pengertian luas, penegakan hukum mencakup penaatan yakni tindakan administratif dan tindakan yustisial, baik keperdataan maupun kepidanaan.

\section{Teori Pengawasan}

Pengawasan secara umum diartikan sebagai suatu kegiatan yang ditujukan untuk menga-

8 Satjipto Rahardjo.(1981). Masalah Penegakan Hukum Suatu Tinjauan Sosiologis. Bandung: Sinar Baru, hlm. 15.

9 Sjachran Basah. (1992). Perlindungan Hukum atas Sikap Tindak Administrasi Negara. Bandung: Alumni, hlm. 14.

10 Dipetik dari Ridwan Tahir. (2012). Perlindungan Hukum Kawasan Hutan Konservasi: Studi tentang Penegakan Hukum Pidana Lingkungan pada Kawasan Taman Nasional. (Disertasi), Program Pascasarjana Universitas Hasanuddin, Makassar, hlm. 176. dakan evaluasi terhadap kegiatan yang akan atau yang telah dilakukan. Pengawasan dapat bersifat preventif dan represif. Pengawasan preventif adalah pengawasan sebelum suatu tindakan dalam pelaksanaan kegiatan, yang biasanya berbentuk prosedur yang harus ditempuh dalam pelaksanaan kegiatan tersebut, sedangkan pengawasan preventif adalah pengawasan yang dilakukan setelah suatu tindakan dilakukan dengan membandingkan apa yang telah terjadi dengan apa yang seharusnya, dan diwujudkan dalam bentuk pemeriksaan setempat, verifikasi, monitoring dan sebagainya.

Menurut George R. Terry, ${ }^{11}$ pengawasan adalah mendeterminasi apa yang telah dilaksanakan, maksudnya mengevaluasi prestasi kerja dan apabila perlu menerapkan tindakan-tindakan korektif hasil pekerjaan apakah sesuai dengan rencana-rencana. Arifin Abdurachman menyatakan bahwa pengawasan adalah kegiatan/proses kegiatan untuk mengetahui hasil pelaksanaan, kesalahan, kegagalan untuk diperbaiki kemudian, dan mencegah terulangnya kembali kesalahan-kesalahan itu, begitu pula mencegah sehingga pelaksanaan tidak berbeda dengan rencana yang telah ditetapkan. ${ }^{12}$

Dalam konteks penegakan hukum lingkungan, khususnya di sektor kehutanan, pengawasan dapat ditujukan terhadap ketaatan aparat penyelenggara dan pelaksana urusan kehutanan atas semua ketentuan peraturan perundang-undangan di bidang

11 Dipetik dari Baso M. (2010). Penerapan Prinsip Pengelolaan Hutan yang Berkelanjutan dalam Aktivitas Pemegang Izin Hak Pengusahaan Hutan di Sulawesi Selatan. (Disertasi), Program Pascasarjana Universitas Hasanuddin, Makassar, hlm. 87.

12 Ibid. 
kehutanan, sehingga diharapkan semua aparat kehutanan yang terlibat dalam hal pelaksanaan pengurusan dan pemanfaatan hutan patuh dan taat untuk menjalankan semua aturan perundang-undangan yang berkaitan dengan kehutanan. Di samping itu pengawasan juga ditujukan terhadap ketataatan masyarakat dan pelaku usaha atas semua aturan perundang-undangan di bidang kehutanan, sehingga diharapkan tindakan atau kegiatan yang dilakukan berjalan sesuai dengan aturan perundang-undangan.

\section{Teori Sanksi}

Sanksi adalah akibat sesuatu perbuatan atau suatu reaksi dari pihak lain atas suatu perbuatan. Menurut van Wijk, ${ }^{13}$ sanksi adalah alat kekuasaan publik yang digunakan oleh penguasa sebagai reaksi atas ketidaktaatan terhadap norma hukum administrasi. Sanksi sebagai alat yang dapat menjamin pelaksanaan norma huukm, tetapi bukanlah ciri yang menentukan norma hukum. ${ }^{14}$

J.B.J.M. ten Berge, ${ }^{15}$ membagi tiga macam sanksi dari segi sasarannya: Pertama, sanksi reparatoir, yakni sanksi yang diterapkan sebagai reaksi atas pelanggaran norma yang ditujukan untuk mengembalikan pada kondisi semula atau menempatkan pada situasi yang sesuai dengan hukum; Kedua, sanksi punitif, yakni sanksi yang semata-mata ditujukan untuk memberikan

13 Ibid., hlm. 91.

14 Lihat Otje Salman dan Anthon F. Susanto. (2007). Teori Hukum: Mengingat, Mengumpulkan, dan Membuka Kembali. Bandung: Refika Aditama, hlm. 97.

15 Habib Adjie. (2007). Sanksi Perdata dan Sanksi Administratif terhadap Notaris sebagai Pejabat Publik. Bandung: Refika Aditama, hlm. 106. hukuman; Ketiga, sanksi regresif, yakni sanksi yang diterapkan sebagai reaksi atas ketidakpatuhan terhadap ketentuan yang terdapat pada ketetapan yang diterbitkan, yang ditujukan untuk mengembalikan pada keadaan semula sebelum terjadinya pelanggaran.

Menurut Philipus M. Hadjon, ${ }^{16}$ penerapan sanksi secara bersama-sama antara hukum administrasi dan hukum lainnya dapat terjadi, yakni kumulasi internal dan kumulasi eksternal. Kumulasi eksternal merupakan penerapan sanksi administrasi bersama-sama dengan sanksi lain seperti sanksi pidana atau sanksi perdata. Adapun kumulasi internal merupakan penerapan dua atau lebih sanksi administrasi secara bersama-sama, misalnya pencabutan izin dan pengenaan denda.

\section{Hutan dan Hutan Lindung}

Berdasarkan data dan informasi dari Dinas Kehutanan dan Perkebunan Kabupaten Sinjai bahwa potensi kehutanan yang ada di kawasan hutan dengan luas 20.370 ha dapat menghasilkan potensi produksi 964,3631 m3 berupa kayu yaitu kayu rimba campuran, meranti, dan jati. Terdapat juga hasil nonkayu lainnya getah damar mata kucing, damar batu, damar kopal, damar pilan, damar rasak, damar daging dan damar gaharu. hasil lainnya madu, gula aren ijuk, kemiri, kenari asam, sutra dan kulit kayu manis.

Berdasarkan data tahun 2014 yang diperoleh dari instansi Dinas Perkebunan dan Kehutanan Kabupaten Sinjai, deskripsi kawasan hutan lindung di Kabupaten Sinjai dapat dilihat pada Tabel 1.

16 Ridwan, H.R. (2011). Hukum Administrasi
Negara. Jakarta: Rajawali Pers, hlm. 317. 
Tabel 1

Luas Kawasan Hutan Dirinci per Kecamatan dan Kelurahan

\begin{tabular}{|c|c|c|c|c|}
\hline No. & Kecamatan & Kelurahan/Desa & Hutan Lindung $(\mathrm{Ha})$ & Hutan Produksi (Ha) \\
\hline \multirow[t]{7}{*}{1} & Sinjai Barat & Turungan Baji & 340 & 763 \\
\hline & & Bontosalama & 240 & 2.085 \\
\hline & & Arabika & 78 & 200 \\
\hline & & Botolempangan & 377 & 500 \\
\hline & & Balakia & 225 & - \\
\hline & & Gunung Perak & 2583 & - \\
\hline & & Barania & 1400 & - \\
\hline \multirow[t]{3}{*}{2} & Sinjai Borong & Batu belerang & 230 & - \\
\hline & & Barambang & 377 & - \\
\hline & & Bonto Katue & 900 & - \\
\hline \multirow[t]{5}{*}{3} & Sinjai Selatan & Talle & - & 200 \\
\hline & & Songing & 465 & - \\
\hline & & Palangka & 317 & - \\
\hline & & Polewali & 587 & 81 \\
\hline & & Puncak & 233 & - \\
\hline \multirow[t]{2}{*}{4} & Tellu Limpoe & Kalobba & 496,375 & - \\
\hline & & Saotengah & 132,500 & - \\
\hline \multirow[t]{7}{*}{5} & Sinjai Tengah & Kompang & 600 & 500 \\
\hline & & Bonto & 345 & - \\
\hline & & Saohiring & 275 & - \\
\hline & & Saotanre & 486,125 & - \\
\hline & & Baru & - & 450 \\
\hline & & Pattongko & 230 & 125 \\
\hline & & Saotengnga & 157 & - \\
\hline \multirow[t]{5}{*}{6} & Bulupodo & Duampanuae & - & 490 \\
\hline & & Tompobulu & - & 1.509 \\
\hline & & & - & 197 \\
\hline & & Lamatti Riattang & - & 2.196 \\
\hline & Jumlah & & 11.074 & 9.296 \\
\hline
\end{tabular}

Sumber: Dinas Perkebunan dan Kehutanan Kabupaten Sinjai, 2014

Tabel 1 di atas menunjukkan lokasi dan luas kawasan hutan lindung yang berada di Kabupaten Sinjai. Adapun mengenai penetapan kawasan hutan lindung langsung ditetapkan oleh Kementerian Kehutanan melalui Peraturan Menteri Kehutanan Nomor P.50/Menhut-II/2011.

Dari 9 (sembilan) kecamatan yang terdapat di Kabupaten Sinjai, terdapat 6 (enam) kecamatan yang mempunyai kawasan hutan lindung. Penulis mengambil sampel penelitian dan menitikberatkan penelitian di Kecamatan Sinjai Barat, Sinjai Tengah, Tellu Limpoe karena berdasarkan informasi awal dari instansi dinas terkait bahwa di 3 kecamatan tersebut merupakan wilayah terbesar kawasan hutan lindung masih bila dibandingkan dengan kecamatan lainnya.

Di Kabupaten Sinjai terdapat beberapa desa yang memiliki hutan lindung di mana keberadaan hutan tersebut tidak dapat diganggu. Oleh karena itu, hutan lindung tersebut harus dapat sebaik mungkin dijaga kelestariannya guna sebagai tempat hidup beraneka ragam flora dan fauna. Kawasan hutan lindung di setiap desa Kabupaten Sinjai tersebut meliputi berbagai daerah seperti Gunung Perak, dan Barania di Keca- 
matan Sinjai Barat, Saotanre di Kecamatan Sinjai Tengah, Desa Kalobba dan Massaile di Kecamatan Tellu Limpoe.

\section{Penegakan Hukum Lingkungan di}

\section{Sektor Kehutanan}

Pemerintah Kabupaten Sinjai dalam menindaklanjuti amanat pelaksanaan UndangUndang Nomor 41 Tahun 1999 telah melaksanakan berbagai upaya yang dianggap perlu dalam mendukung upaya pelestarian hutan. Hal ini ditandai dengan terbitnya beberapa produk hukum yang mendukung upaya tersebut antara lain Peraturan Daerah No. 28 Tahun 2012 tentang Rencana Tata Ruang Wilayah Kabupaten Sinjai Tahun 20122032.

Sebelumnya, Pemerintah Kabupaten Sinjai melalui Surat Edaran Bupati Sinjai No. 622/326/Set Tahun 2004 telah mengatur larangan memiliki chainsaw (gergaji mesin) tanpa izin pemerintah daerah yang diedarkan kepada semua camat dan lurah di lingkungan Pemerintah Kabupaten Sinjai. Hal ini antara lain dimaksudkan untuk mengendalikan penebangan liar, yang cenderung merusak hutan dan fungsinya sehingga kepemilikannya dibatasi dengan izin.

Selain hal tersebut, Pemerintah Kabupaten Sinjai telah menerbitkan Perda No. 177 Tahun 2014 tentang Penempatan Wilayah Kerja Polisi Hutan dan Petugas Pembantu Pengamanan Hutan. Perda ini juga menetapkan 60 orang petugas yang akan melaksanakan pengamanan dan patroli kawasan hutan sepanjang tahun.

Pemerintah Kabupaten Sinjai menekankan pada upaya preventif dalam melaksanakan perlindungan hukum bagi kawasan hutan lindung. Setiap periode tertentu, pihak Dinas Perkebunan dan Kehutanan Kabupaten Sinjai melaksanakan sosialisasi dan penyuluhan terkait pentingnya perlindungan fungsi hutan. Bencana tanah longsor dan banjir bandang yang pernah terjadi cukup mengingatkan masyarakat akan bahaya yang ditimbulkan oleh penebangan liar.

Dari data yang diperoleh dari pihak Dinas Perkebunan dan Kehutanan Kabupaten Sinjai yang mengatakan sering melakukan sosialisasi dan penyuluhan tentang perlindungan dan pelestarian kawasan hutan lindung kepada masyarakat, terdapat perbedaan di lapangan karena sebagian besar responden selama 3 tahun hanya pernah mengikuti 1-2 kali penyuluhan yaitu sebanyak 16 responden, sedangkan jumlah yang tidak pernah mengikuti penyuluhan sebesar $62 \%$ sebanyak 31 responden, dan lebihnya hanya 3 responden yang mengikuti di atas 3 kali penyuluhan tentang sosialisasi yang dilakukan oleh pihak dinas terkait. Artinya, intensitas sosialisasi yang dilaksanakan sangat jarang. Namun dari hasil wawancara dengan Asnawir, dikatakan bahwa sebenarnya pihaknya sering melakukan sosialisasi dan pelatihan terkait dengan perlindungan dan pelestarian hutan lindung yaitu 1 - 2 kali pertahun, namun karena keengganan masyarakat untuk mengikutinya sehingga kebanyakan hanya aparat desa dan kelurahan yang mengikuti sosialisasi dan pelatihan tersebut.

Terkait kegiatan patroli petugas polisi hutan yang ditetapkan dalam Keputusan Bupati No. 177 Tahun 2014 membagi wilayah kerja dalam 41 unit lokasi dengan masing masing patroli berisi 5 sampai 6 orang personil setiap minggunya, lanjut Asnawir tentang 
penegakan dalam sektor hukum lingkungan telah dilakukan dengan baik dan sesuai dengan ketentuan yang berlaku. Hal ini didukung dengan observasi langsung ke lapangan setiap satu (1) minggu sekali. ${ }^{17}$

Dalam rangka merealiasikan rencana perlindungan hutan yang sebaik mungkin, maka Pemerintah Kabupaten Sinjai telah mengangkat 64 orang tenaga Polhut yang terdiri dari PNS dan honorer, yang melaksanakan patroli rutin. Data menunjukkan bahwa patroli yang dilakukan oleh pihak polisi hutan sudah baik. Hal ini sesuai dengan apa yang disampaikan oleh pihak Dinas Perkebunan dan Kehutanan Kabupten Sinjai yang telah mengatur jadwal patroli sedemikian rupa dengan personil yang mencukupi sehingga perambahan hutan oleh masyarakat dapat dicegah dengan baik.

Meskipun demikian, kadangkala pihak polisi hutan juga banyak menemui kendala utamanya jika pelaku perambahan atau penebangan liar berjumlah banyak, lebih banyak dari personil patroli, dan kadang mereka juga melengkapi diri dengan senjata rakitan. Hal ini diakui oleh pihak polisi hutan, berdasarkan hasil wawancara dengan Samsuraedah, ${ }^{18}$ yang menerangkan bahwa kadangkala petugas patroli jika menemui pelaku penebangan liar, mereka terdesak karena pelaku selalu berjumlah lebih lebih banyak dan untuk itu mereka harus meminta bantuan dari pihak kepolisian Resort Sinjai. Biasanya, jika polisi hutan melakukan patroli sebanyak 1 atau 2 orang personil dari pihak kepolisian yang

17 Wawancara dengan Asnawir, S.Pi, staf Dinas Perkebunan dan Kehutanan Kabupaten Sinjai, 24 Agustus 2014.

18 Wawancara dengan Samsuraedah, tanggal 2 September 2014 ikut dalam patroli, dan jik ada laporan peristiwa di kawasan hutan maka pihak kepolisian ikut dalam patroli tersebut.

\section{Sinergitas Antarinstansi dalam Penegakan} Hukum Lingkungan di Sektor Kehutanan Di masa lalu, banyak pihak mengkritisi kinerja Polri terkait pelaksanaan tugas dan tanggung jawabnya selaku aparatur negara pengemban fungsi pemelihara keamanan dan ketertiban masyarakat. Hal ini muncul mengingat pada masa itu kinerja aparat Polri bagi sebagian pihak dianggap kurang agresif, kurang responsif dan tidak profesional, bahkan terkesan militeristik, khususnya dalam mengatasi berbagai permasalahan hukum yang dihadapi masyarakat.

Pemerintah Kabupaten Sinjai dalam menindaklanjuti amanah pelaksanaan Undang-Undang Nomor 41 Tahun 1999 telah melaksanakan berbagai upaya yang dianggap perlu dalam mendukung upaya pelestarian hutan. Hal ini ditandai dengan terbitnya beberapa produk hukum yang mendukung upaya tersebut antara lain Peraturan Daerah No. 28 Tahun 2012 tentang Rencana Tata Ruang Wilayah Kabupaten Sinjai Tahun 2012-2032.

Sebelumnya, pemerintah Kabupaten Sinjai melalui Surat Edaran Bupati Sinjai No. 622/326/Set tahun 2004 telah mengatur larangan memiliki Chainsaw (Gergaji Mesin) tanpa izin pemerintah daerah yang diedarkan kepada semua Camat dan Lurah di lingkungan Pemerintah Kabupaten Sinjai. Hal ini antara lain dimaksudkan untuk mengendalikan penebangan liar, yang cenderung merusak hutan dan fungsinya sehingga kepemilikannya dibatasi dengan izin. 
Selain hal tersebut, Pemkab Sinjai telah menerbitkan Perda No. 177 Tahun 2014 tentang Penempatan Wilayah Kerja Polisi Hutan dan Petugas Pembantu Pengamanan Hutan. Menurut Asnawir, observasi hutan dilakukan untuk mengawasi kondisi hutan, dan jika terjadi pelanggaran atau kejadian di kawasan hutan lindung ini baik yang dilakukan oleh masyarakat akan dilaporkan kepada pihak kepolisian. Hal ini sejalan dengan yang disampaikan oleh pihak kepolisian dalam hal ini Andi Rahmat, selaku Kasat Reskrim Polres Sinjai, bahwa kasus-kasus seperti illegal logging atau perambahan hutan yang menjadi temuan pihak polisi hutan maka langsung dilaporkan kepada pihak kepolisian untuk mendapat tindak lanjut. ${ }^{19}$

Menurut wawancara yang dilakukan dengan pihak Kejaksaan bahwa penegakan hukum lingkungan di Kabupaten Sinjai sejauh ini telah diterapkan, hal ini dapat dilihat dari segi efektivitas beberapa lembaga penegak hukum di sektor kehutanan berbagai kinerja sesuai prioritasnya masing-masing, seperti halnya dengan polisi kehutanan yang sering melakukan patroli. Kasus yang pernah ditangani di sektor kehutanan salah satunya adalah illegal loging, ada beberapa kasus yang terjadi dan diproses di Kejaksaan mulai tahun 2011-2014 yag kemudian dilanjutkan ke pengadilan dan semua sudah diputuskan sebanyak 4 (empat) kasus.

Sinergitas antara polisi kehutanan dan pihak kepolisian selama ini masih ada yang kurang sejalan, misalnya saja jika polisi kehutanan menemukan kasus yang terjadi di kawasan hutan yang kemudian dilimpahkan ke pihak kepolisian, namun sampai kasus

\footnotetext{
19 Wawancara tanggal 24 Juni 2014
}

tersebut dipihak kepolisian hanya berujung pada perdamaian, padahal dari pihak polisi kehutanan beranggapan bahwa kasus tersebut merupakan sebuah pelanggaran.

Kurangnya fasilitas dalam melaksanakan patroli juga sangat berpengaruh. Dalam salah satu patroli di kawasan hutan pernah terjadi perlawanan sehingga 2 orang dari anggota polisi hutan disandra, hal ini dapat diselesaikan setelah pihak kepolisian dan pemerintah setempat turun tangan mendamaikan. Hal ini antara lain karena masyarakat masih beranggapan bahwa hutan di sekeliling desa mereka adalah miliknya, yang diwariskan dari nenek moyang secara turun-temurun.

Namun jawaban pihak kepolisan dari keterangan pihak polisi Kehutanan oleh Andi Rahmat, bahwa sinergitas antara institusi hukum dan kehutanan sudah sejalan. Jika ada laporan maka akan diproses dan langsung melanjutkan pada tahap penyidikan seperti kasus illegal loging dan perambahan hutan, di mana selama ini kasus pelanggaran dikawasan kehutanan biasanya diselesaikan sampai di pengadilan atau dipidanakan. Namun ada juga beberapa kasus yang tidak sampai dipidanakan. ${ }^{20}$

Dari sisi badan peradilan, pada tahun 2013 ada 1 kasus hutan lindung, dan menurutnya selama ini sinergitas sudah cukup baik (lihat Tabel 2). Baik dari aparat instansi hukum maupun instansi kehutanan dan hanya menerima berkas perkara kemudian diadili dan diputuskan. Namun, ada beberapa permasalahan dalam pelaksanaan persidangan salah satunya adalah barang bukti yang tidak ada koordinasi seperti kayu, biasanya tidak

\footnotetext{
$20 \quad$ Wawancara tanggal 2 juni 2014
} 
dihadirkan tetapi hanya menjadi titipan saja. Selama ini faktor-faktor yang mempengaruhi hal tersebut adalah tidak jelasnya tapal batas/zona batas kawasan.

\section{Tabel 2}

Perkara Terkait Hutan Lindung di Pengadilan Negeri Sinjai

\begin{tabular}{ccl}
\hline No. & Tahun & \multicolumn{1}{c}{ Perkara } \\
\hline 1 & 2009 & $\begin{array}{l}\text { No.18/PID.B/2009/PN SINJAI. } \\
\text { No.52/PID.B/2009/PN SINJAI. }\end{array}$ \\
\hline 2 & 2010 & No.40/PID.B/2010/PN SINJAI. \\
\hline 3 & 2012 & $\begin{array}{l}\text { No.100/PID.B/2012/PN SINJAI. } \\
\text { No.101/PID.B/2012/PN SINJAI. }\end{array}$ \\
\hline 4 & 2013 & No.86/PID.B/2013/PN SINJAI. \\
\hline
\end{tabular}

Sumber: Pengadilan Negeri Sinjai, 2014.

Tabel 2 menunjukkan bahwa meskipun pemerintah Kabupaten meletakkan prioritas pada penegakan hukum preventif, serta memelihara kelestarian hutan lindung, namun harus diakui belum optimal pada tataran praktis. Oleh karena itu penegakan secara represif masih tetap diperlukan dan dihidupkan. Adanya 5 (lima) kasus terkait hutan lindung yang diproses di Pengadilan Negeri Kabupaten Sinjai dalam kurun waktu 4 tahun terakhir menunjukkan bahwa penegakan preventif yang mengutamakan pemahaman atas ketentuan hukum belum mencapai hasil yang optimal, meskupunsebenarnya sudah memadai.

Bila disimak dengan baik keterangan pihak penegak hukum terkait (lihat hasil wawancara) diperoleh petunjuk bahwa belum optimalnya penegakan hukum preventif disektor kehutanan ini disebabkan oleh dua faktor yaitu koordinasi antara instansi terkait dan fasilitas pengawasan yang belum sepenuhnya mendukung upaya ini. Di samping itu faktor lain sebagaimana kondisi yang ditemui di lapangan seperti zonasi dan patok pembatas yang kurang.

\section{Faktor-faktor yang Mempengaruhi} Penegakan Hukum di Sektor Kehutanan

Pokok penegakan hukum sebenarnya terletak pada faktor-faktor yang mungkin mempengaruhinya. Faktor-faktor tersebut mempunyai artiyang netral, sehingga dampak positif atau negatifnya terletak pada isi faktor-faktor tersebut. Faktor-faktor tersebut adalah, sebagai berikut: Pertama, faktor hukumnya sendiri, dalam hal ini dibatasi pada undang-undang saja; Kedua, faktor penegak hukum, yakni pihak-pihak yang membentuk maupun menerapkan hukum; Ketiga, faktor sarana atau fasilitas yang mendukung penegakan hukum; Keempat, faktor masyarakat, yakni lingkungan dimana hukum tersebut berlaku atau diterapkan; dan Kelima, faktor kebudayaan, yakni sebagai hasil karya, cipta, dan rasa yang didasarkan pada karsa manusia di dalam pergaulan hidup.

Kelima faktor tersebut saling berkaitan dengan eratnya, oleh karena merupakan esensi dari penegakan hukum, juga merupakan tolak ukur daripada efektivitas penegakan hukum. Dalam menjalankan fungsinya untuk melindungi kawasan hutan di Kabupaten Sinjai, pihak polisi kehutanan (Polhut) mengalami kendala dalam hal menghadapi pelaku pembalakan liar yang menggunakan senjata rakitan. Salah satu harapan yang dilontarkan oleh pihak Polisi Hutan adalah kiranya mereka dapat dibekali senjata api dengan mengikuti ketentuan peraturan yang ada tentang senjata api tersebut. 
Hasil penelitian menunjukkan bahwa sebenarnya hingga saat ini sudah sangat jarang terjadi kasus-kasus tindak pidana di sektor kehutanan semisal illegal loging dan pembukaan lahan di kawasan hutan lindung. Hal ini mengindikasikan bahwa sebenarnya mayoritas masyarakat sudah takut untuk melakukan perambahan hutan di sekitar kawasan hutan lindung, di mana 31 orang atau $62 \%$ responden mengakui hal tersebut, sedangkan 8 orang atau 16\% lainnya mengatakan hal tersebut sudah jarang terjadi dan selebihnya menurut responden masih ada yang melakukan hal tersebut namun hanya 1-2 orang saja.

Namun di lain sisi, ada pula yang beralasan bahwa masyarakat melakukan perambahan hutan dan membuka lahan karena tidak mengatahui bahwa kawasan tersebut telah masuk kawasan hutan lindung, hal ini dikarenakan patok tanda kawasan yang dibuat oleh pihak dinas sangat jarang ditemukan, bahkan sebagian responden mengatakan bahwa belum ada tanda yang dipasang oleh pihak dinas yang menandakan daerah batas-batas kawasan hutan lindung.

\section{PENUTUP}

Efektivitas penegakan hukum di sektor kehutanan dalam melindungi kawasan hutan lindung di Kabupaten Sinjai sudah cukup memadai, meskipun intensitasnya perlu ditingkatkan agar terlaksana perlindungan yang lebih optimal. Kerjasama antarinstansi yang terlibat dalam penegakan hukum dalam perlindungan terhadap hutan lindung di Kabupaten Sinjai sudah cukup baik, hal ini ditandai dengan terbitnya Keputusan Bupati tentang Perizinan memiliki gergaji mesin,
Beberapa faktor yang memengaruhi upaya perlindungan terhadap kawasan hutan lindung antara lain minimnya tanda batas yang memberikan informasi bahwa kawasan tersebut kawasan yang dilindungi, kurangnya perhatian dan partisipasi warga masyarakat dalam sosialisasi yang dilaksanakan oleh pihak Dinas Perkebunan dan Kehutanan Kabupaten Sinjai.

Perlindungan hukum terhadap kawasan hutan lindung perlu ditingkatkan dengan meningkatkan penyuluhan dan sekaligus mengusahakan agar penyuluhan yang dilaksanakan tidak sekadar formalitas. Perlu penambahan rambu rambu atau penanda yang jelas tentang di mana batas-batas wilayah yang termasuk sebagai hutan lindung agar masyarakat dapat mengetahui apakah wilayah yang hendak dibuka sebagai lahan pertanian masuk kawasan hutan lindung atau tidak. Jumlah polisi hutan yang ditugaskan untuk melakukan patroli demi menjaga agar tidak terjadi perambahan hutan lindung oleh masyarakat telah cukup banyak, akan tetapi perlu dipertimbangkan untuk memberikan senjata api untuk kebutuhan patroli tersebut. Selain itu, perlu dipertimbangkan agar bagi polisi hutan untuk yang berpatroli di wilayah yang terpencil juga diberikan kendaraan patroli yang sesuai serta honorarium yang lebih layak.

\section{BIBLIOGRAFI}

Agung Nugraha. (2004). Menyonsong Perubahan Menuju Evitalisasi Sektor Kehutanan. Jakarta: Wirma Aksara.

Baso M. (2010). Penerapan Prinsip Pengelolaan Hutan yang Berkelanjutan dalam Aktivitas Pemegang Izin Hak Pengusahaan Hutan di Sulawesi Selatan. (Disertasi), Program Pascasarjana 
Universitas Hasanuddin, Makassar.

Habib Adjie. (2007). Sanksi Perdata dan

Sanksi Administratif terhadap Notaris sebagai Pejabat Publik. Bandung: Refika Aditama.

Harian Kompas, Rabu, 24 Juni 2009.

Iskandar. "Aktualisasi Prinsip Hukum Pelestarian Fungsi Lingkungan Hidup dalam Kebijakan Perubahan Peruntukan, Fungsi, dan Penggunaan Kawasan Hutan". Jurnal Dinamika Hukum, 11(3) 2011: 532-547

Merdeka.com pada laman website: merdeka . com/pernik/158-tewas-dalam-banjirbandang-di-sinjai-sulsel-bmshx8p. $\underline{\mathrm{html}}$, [Diakses pada tanggal 6 Februari 2014].

Otje Salman dan Anthon F. Susanto. (2007). Teori Hukum: Mengingat, Mengumpulkan, dan Membuka Kembali.
Bandung: Refika Aditama.

Pemerintah Kabupaten Sinjai. Dikutip pada laman website: http://www.sinjaikab. go.id/v2/index.php? option =com content\&view $=$ article\&id $\quad$ [Diakses pada tanggal 16 Mei 2014].

Ridwan Tahir. (2012). Perlindungan Hukum Kawasan Hutan Konservasi: Studi tentang Penegakan Hukum Pidana Lingkungan pada Kawasan Taman Nasional. (Disertasi), Program Pascasarjana Universitas Hasanuddin, Makassar.

Ridwan, H.R. (2011). Hukum Administrasi Negara. Jakarta: Rajawali Pers.

Satjipto Rahardjo. (1981). Masalah Penegakan Hukum Suatu Tinjauan Sosiologis. Bandung: Sinar Baru.

Sjachran Basah. (1992). Perlindungan Hukum atas Sikap Tindak Administrasi Negara. Bandung: Alumni. 